\title{
Modelling drivers of Koha open source library system using partial least squares structural equation modelling
}

\author{
A.M. Zainab ${ }^{1,2}$, K.Kiran ${ }^{2 *}$, T. Ramayah ${ }^{3}$ and N.H.A. Karim ${ }^{4}$ \\ 1, 2 Department of Library and Information Science, \\ Faculty of Computer Science and Information Technology \\ University of Malaya, Kuala Lumpur, MALAYSIA \\ ${ }^{3}$ School of Management, Universiti Sains Malaysia, \\ Pulau Pinang, MALAYSIA \\ ${ }^{4}$ International Islamic University Malaysia, \\ Kuala Lumpur, MALAYSIA \\ E-mail: zainabajab@siswa.um.edu.my; *kiran@um.edu.my (corresponding author); \\ ramayah@usm.my; nharun57@gmail.com
}

\begin{abstract}
Open source library systems are markedly a less expensive alternative to licensed library systems, but the uptake by libraries in the developing countries has been slower than expected. Focusing on the user, this study employs a human behavior analysis approach to ascertain what factors drive librarians to accept an open source library information system, specifically the Koha library system. This exploratory study is guided by two important components of technology acceptance, the Unified Theory of Acceptance and Use of Technology and the User Acceptance Test. Using a survey questionnaire, data was collected from 245 librarians from five public and private university libraries and analyzed using the PLS-SEM method. Librarians' attitude towards using technology and social influence are the key determinants of open source library system acceptance. At the same time, system quality and information quality are also two other significant predictors of librarians' acceptance of open source technology. This study is the first to conceptually integrate technology acceptance predictors and open system success indicators, as used in user acceptance tests, to understand open source library system acceptance and use among university librarians. The identified major predictors can be used by library management to devise strategies to improve librarians' involvement and use of open source systems.
\end{abstract}

Keywords: Open source; Library systems; Koha, Partial Least Square Path Modelling; Structural Equation Modelling.

\section{INTRODUCTION}

University librarians increasingly need efficient and effective systems to support routine activities such as acquisitions, cataloguing and classification, management of learning resources, repositories and supporting research. The library systems used in carrying out these tasks are complex systems, designed and developed by vendors who continue to have the upper hand in the functions and costing of these systems. Librarians' reliance on proprietary systems has, to some extent, hindered the ability of libraries to shape their functions and services to better serve their clientele. Rao (2014) is of the opinion that open 
source for library automation needs librarians' engagement and empowerment through means of open technology skills for in-house service and system operation. The open source system features and functions are evaluated and ranked to be the most demanding application with least cost (Gireesh Kumar and Jayapradeep 2015; Madhusudhan and Singh 2016). Thus it serves as a cost effective solution for libraries which can be customized according to the local user requirements (Gireesh Kumar 2016). Sadly, the uptake of open source solutions has been reported to be at much lesser pace than expected (Singh 2017). Kampa (2018) believes that this could be due to the fact that young professionals lack awareness and knowledge of open source technology.

There are various open source systems available in the market, namely Koha, Lucidea, Mandarin, OPALS, OpenBiblio, NewGenLib, Evergreen, ABCD, MarcoPolo and PhpMylibrary (Jaffe and Careaga 2007). The possibility of the use of these systems is extensive. However, the rate of open source adoption by libraries is far below the other sectors, and libraries have yet to commit to open source solutions and development (Singh, 2017). Several researchers believe that librarians' technical knowledge and skills are the main problem. Gireesh Kumar (2016) reports that the lack of technical knowhow and support, along with skilled staff to install and man the system, may have an impact on the use of open source systems in Indian libraries, though Kampa (2018) revealed that the level of awareness and use of Koha is very high among LIS professionals in India. Eckhardt et al. (2009) and Raza et al. (2015) as well as Todd (2018) claim that an open source system is designed for technically adept users and there is a great distinction in the roles between developers and users. The question is 'who are the developers and who are the users?' Chudnov (1999) had clearly stated that the developers are also the users and vice versa, and the open source community consist of both technical and non-technical users. Thus, librarians (as users) are developers of open access solutions, if they decide to adopt open access library systems and prepare themselves to be technically apt in maximizing the benefits of the free open code to suit their library's needs.

Chudnov (1999) in his discussion on the future of library systems, had alerted librarians on the potential of open source library systems. In 2000, the open source system interest group was developed, Library Information Technology Association (LITA), to promote open source solution adoption in libraries. The first open source integrated library system (ILS) was developed for the use of Horowhenua Library Trust (HLT) by Katipo Communications Limited of Wellington, New Zealand. This initiative was a response to the increasing cost of DOSbased systems. Open source tools such as Perl, MySQL and Apache were introduced by Katipo to develop a new system. Officially, on 3rd of January 2000, Koha, the first open source library system software was released. Since then, there has been a high demand for Koha. The early adopters of Koha are from New Zealand, Australia, Canada, United States of America, India, Thailand, United Kingdom and France. Initially, Koha adopters were mainly school and special libraries. In year 2000, Koha won the Innovation in Libraries award (Jaffe and Careaga 2007). Koha 3.0 was released in 2005, and its development has since expanded as librarians continually collaborate to evolve the functions and features of the system.

Although Koha is the most widely adopted and used open source solution (Edem 2016; Tella and Oladeji 2017), the uptake has been slow in several countries (Singh, 2017). It would be assumed that developing countries would have been in the forefront to take advantage of a technology which was not proprietary based, but in reality it is not as such. Several studies indicate the lack of technology skills and increased documentation to be the main reason Koha has not been widely adopted as expected (Singh 2014; Oyelude 2016). To date there has been a lack of understanding the uptake of open source system from the aspect of 
human behavior. Librarians' acceptance of open source system adoption, particularly in developing countries is necessary. Hence, the objective of this study is to investigate university librarian's acceptance of Koha using a proposed open source information system (OSIS) acceptance model.

\section{LITERATURE REVIEW}

\section{Koha Open Source Library Information System}

Oyelude (2016) reviewed the literature on open source software for library systems published in the year 2016. His critical investigation into 18 publications revealed that open source technology has indeed made its way into the library as a solution to overcome financial barriers of proprietary software. He found that though countries such as India and Nigeria were using Koha based library systems, the benefits were hindered due to lack of technological skills and support. These views had earlier been highlighted by several researchers as well. Riewe (2008) analysed the open source integrated library systems in the context of documentation of proprietary and open source systems. His study concluded that open source systems need smoother installation processes and complete documentation. These issues are significant barriers to the adoption of open source systems. Singh (2014) also reported on technical support, users' experiences and expectations of using the open source system. He claims that the biggest challenge relates to library staffs' attitude. Librarians had positive experiences while using the system with technical support, but they criticized the unpaid technical support. Open source solutions with established developers and users tend to produce higher quality systems, which are more functional and beneficial to the system community.

The technological advancement has impact and influence on organization and individual behavior (Delone and McLean 2002). The organizational and individual concern are mainly on system quality. Madhusudhan and Singh (2016) conducted a comparative analysis of Koha, Libsys, NewGenLib, and Virtua based on ten broad criteria. Koha (open source) was found to be the second highest ranked after Virtua (commercial) based on the achievement of 72.9 percent of a 280 score. Koha scored well as it is more flexible as compared to NewGenLib, Libsys and Virtua. Koha's flexibility refers to it being customizable, modifiable and expandable according to the requirement of the library and their patrons. Suggestions to improve Koha included availability of indexing module, digital data creation and availability in diverse languages.

Although the public sector is investing in proprietary software, the issues of dependency on vendor still exists (Adnan and Lee 2015). The librarians remain concerned about the utilization of this investment as the monopoly of proprietary systems can be replaced by free open source technology systems.

Several issues impend open source library information system's success. The hesitation by librarians and varied perception between system developers and librarians are the barriers of open source adoption and implementation in the library (Heeks 2002; Jaffe and Careaga 2007; Singh 2017). Furthermore, the developers are focusing on software strength while librarians are concern about job performance, satisfaction, system quality and information quality to achieve organization objectives (Meissonier and Houze 2010; Raza 2015). Consequently, the librarians will continue to use and support the expensive proprietary library system. Lack of understanding and confidence in open source technology solution by the librarians, skewed perception of open systems, social influence, attitude towards using 
technology, lack of self-efficacy to undertake the library operations and services, misconception that open source systems are only for libraries with a small collection and evidences of open source projects failure, have created a doubt among librarians to adopt open source technology systems. Another factor is the decreasing budget has eventually directed the public and private university libraries towards a cost saving solution as in Malaysia (Adnanh and Lee 2015), Pakistan (Rafiq and Ameen 2009), Kazakhstan (Zhussupova and Rahman 2011), Europe (Cassell 2008), Sri Lanka (Jayawardena and Dias 2011), Western Cape School in South Africa (Johnston et al. 2013) and India (Vimal Kumar and Jasimudeen 2012).

Adnanh and Lee (2015) reported that in Malaysia, open source software raises a lot of issues relating to implementation rejection, policies, system downtime, open source knowledge among users, technology skills of software developers and non-IT users, and user perceptions. Rahim et al. (2006) used a multiple perspective framework (MPF) to measure information system quality based on the technology-organization-environment (TOE) model to guide and understand the criteria that influence appropriation of the open source system process which will lead to system adoption. Rahim and Zairah (2009) also reported on a multiple framework used to facilitate implementation and use of open source system in Malaysian public sector organizations. Abu Bakar et al. (2015) conducted a study on Koha integrated library system in Malaysia reporting a significant rise in open source adoption between 2008 - 2014. This was attributed to the support by the Malaysian Administrative Modernization and Management Planning Unit (MAMPU), which focusses on public sector's open source development projects. A 95 percent success rate of open source implementation in public sectors was reported by MAMPU (2016), however this encouraging percentage includes mainly public sector's adoption of open source inventory systems. Library adoption of open source systems is less encouraging. As at July 2016, Malaysia has reported a total of 27 Koha users only, mainly in colleges (14), private universities (4), special libraries (4), public universities (2) and other non-educational institutions (3). The reason behind the slow uptake is yet unknown.

\section{CONCEPTUAL FOUNDATION}

The underlying concept of the proposed acceptance model was to understand what influences users to adopt a new technology based system, in this case the Koha open source system. The concept was created to define the flow of "lead" and "need" for a user acceptance study. Figure 1 shows the underlying conceptual framework which supports user behaviour in the acceptance of technology. The base of this framework is the Unified Theory of Technology Acceptance, UTAUT, by Venkatesh et al (2003), which is extended to include constructs from Delone and McLean's (2002; 2003) information system success model, as used in a user acceptance test, UAT). UTAUT is considered as the most important theory for technology adoption studies (Min et al. 2008). It has been consistently used, either in its original form or modified form, to measure various types of technology acceptance and use. Dulle and Minishi-Majanja (2011) supported that UTAUT is suitable in understanding the factors influencing researchers' acceptance and use of open access systems. Zainab et al. (2018) had tested the reliability of a modified UTAUT model to examine the acceptance of RFID technology in Malaysian libraries, and found it to be consistent with the original UTAUT. However, as Ventakesh et al. (2003) advised, modifications and revisions to UTAUT are needed as deemed appropriate to the technology under study. 


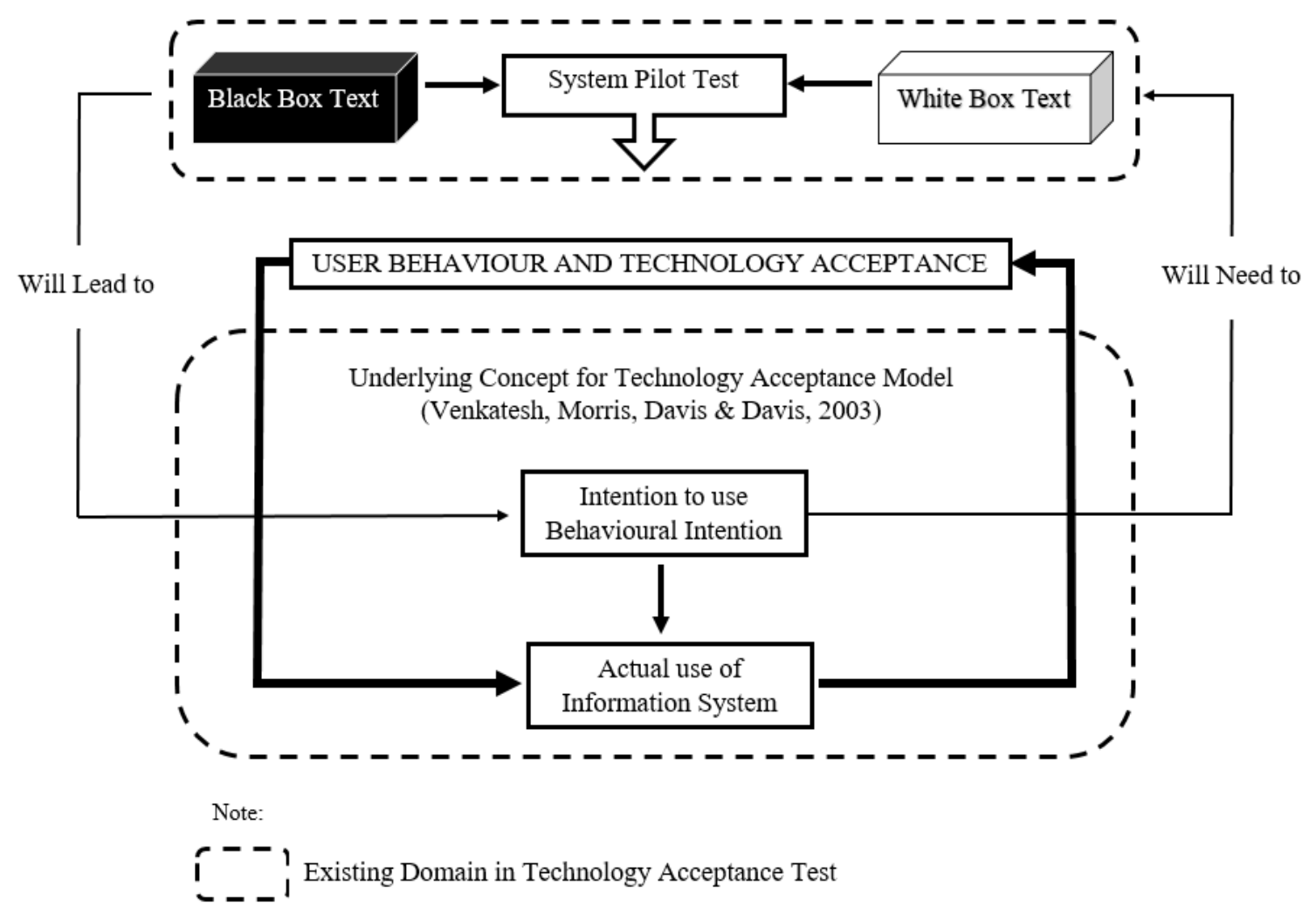

Figure 1: Underlying concept of the OSIS acceptance model

The acceptance gap between software developers and system users is identified in the information system acceptance literature. Min et al. (2008) had proposed cost, system quality and information quality to be incorporated in future UTAUT model. Behavioral models lack functional and technical aspects of technology use. A system pilot test is performed to evaluate the aspects of system functionalities and capabilities. This involves two main tests, the Black box and the White box, which are considerably of great advantage to the developer. The black box test is used to test the program functions built by the developer of a system. The technique relies on evaluating users' input. There are classes of data which are tested to ensure the system functions and response accordingly with users' input. The white box is used for testing the structure of a system. Therefore, these technical aspects of the proprietary system are only evaluated during the pilot test without much enhancement to the system. Both the black box test and the white box test tend to benefit the vendor with little direct benefit to the users of the system. The pilot test is purely for technical aspects (system functionalities and capabilities) as it ignores the actual user evaluation, i.e. system acceptance.

The present open source technology is developed using a source code to suit both the technical and non-technical users (Abu Bakar et al. 2015). In which case both users and developers are considered as a single entity. Users' involvement begins at an early stage of development and continues till system evaluation. The user involvement drives the technology acceptance success and brings the users and organization to a mutual understanding of system acceptance and use. Venkatesh et al. (2003) believe that user involvement is the key for user behavior predictors for technology acceptance, which leads to high implication towards system adoption. This concept is applied in this study to propose and test an open source system acceptance model. 


\section{Open Source Information System (OSIS) Acceptance Model}

The OSIS acceptance model is designed to measure user behavioral expectations of a library information system. This study intends to integrate behavioral acceptance (as depicted in UTAUT) and system functional acceptance (as depicted by UAT). Table 1 explains the nine constructs defined and developed for the OSIS model.

Table 1: Construct Description of the OSIS Acceptance Model

\begin{tabular}{|c|c|c|}
\hline Construct & Definition & Measuring Variables \\
\hline \multicolumn{3}{|l|}{ UTAUT Constructs } \\
\hline $\begin{array}{l}\text { Performance Expectancy } \\
\text { (PE) }\end{array}$ & $\begin{array}{l}\text { User's job performance in using an open source } \\
\text { library information system. }\end{array}$ & $\begin{array}{l}\text { Usefulness of the system, tasks } \\
\text { accomplishment, tasks productivity and } \\
\text { job effectiveness. }\end{array}$ \\
\hline Effort Expectancy (EE) & $\begin{array}{l}\text { Evaluating the user and system interaction for } \\
\text { an open source library information system }\end{array}$ & $\begin{array}{l}\text { Ease of use, user and system } \\
\text { interaction, system command and easy } \\
\text { to learn. }\end{array}$ \\
\hline Social Influence (SI) & $\begin{array}{l}\text { The influence by individual characteristic and } \\
\text { others for the use of an open source library } \\
\text { information system }\end{array}$ & $\begin{array}{l}\text { Users' behaviour, library association, } \\
\text { professionals, top management. }\end{array}$ \\
\hline Self-Efficacy (SE) & $\begin{array}{l}\text { The user's confidence level, ability and believe } \\
\text { on an open source library information system }\end{array}$ & $\begin{array}{l}\text { Built-in system help, other help for } \\
\text { user, self-expertise in using system. }\end{array}$ \\
\hline $\begin{array}{l}\text { Attitude towards using } \\
\text { technology (ATUT) }\end{array}$ & $\begin{array}{l}\text { The user's favor or disfavor, way of thinking, } \\
\text { norm characteristics and habits to use an open } \\
\text { source library information system }\end{array}$ & $\begin{array}{l}\text { System friendliness, practice, exposure } \\
\text { to open system, impression on system } \\
\text { and likelihood of system usage. }\end{array}$ \\
\hline \multicolumn{3}{|l|}{ UAT Constructs } \\
\hline $\begin{array}{l}\text { Information Technology } \\
\text { Skill (ITS) }\end{array}$ & $\begin{array}{l}\text { Users' Information Technology Knowledge, } \\
\text { technical skill and computer skill in handling an } \\
\text { open source library information system }\end{array}$ & $\begin{array}{l}\text { Technical use, ICT knowledge, ease to } \\
\text { develop, ease to maintain, } \\
\text { programming proficiency, open system } \\
\text { competencies. }\end{array}$ \\
\hline System Quality (SQ) & $\begin{array}{l}\text { The interrelation or connectivity between } \\
\text { system components and dependability, flow of } \\
\text { an open source library information system in } \\
\text { terms of response time, integration, reliability } \\
\text { and portability }\end{array}$ & $\begin{array}{l}\text { System platform, integration, } \\
\text { processing capacity, independent } \\
\text { modules, respond time, system } \\
\text { standard. }\end{array}$ \\
\hline Information Quality (IQ) & $\begin{array}{l}\text { The information that resides in an open source } \\
\text { library information system is evaluated based } \\
\text { on data standard, information organization, } \\
\text { data accuracy }\end{array}$ & $\begin{array}{l}\text { Data format, response upon faulty } \\
\text { input, data recovery, accuracy of data } \\
\text { searching, matching and mapping of } \\
\text { data. }\end{array}$ \\
\hline Cost (C) & $\begin{array}{l}\text { Price for an open source library information } \\
\text { system, training and maintenance }\end{array}$ & $\begin{array}{l}\text { Budget, ownership system, user } \\
\text { training, system maintenance and } \\
\text { system market value. }\end{array}$ \\
\hline \multicolumn{3}{|l|}{ OSIS Acceptance } \\
\hline $\begin{array}{l}\text { Acceptance of Koha Open } \\
\text { Source Library } \\
\text { Information System } \\
\text { (ATUKOSLIS) }\end{array}$ & $\begin{array}{l}\text { User's behavior of effort put into, willingness } \\
\text { to use, recommend and value the system } \\
\text { which gives impact to organizational decision } \\
\text { making for an open source library information } \\
\text { system adoption and implementation, } \\
\text { technological acceptance and individual job } \\
\text { commitments. }\end{array}$ & $\begin{array}{l}\text { Users' willingness to use system, } \\
\text { support system adoption, recommend } \\
\text { the open system, accept the } \\
\text { implementation decision-making. }\end{array}$ \\
\hline
\end{tabular}

The OSIS acceptance model with its related variables and relationships are shown in Figure 2. It has nine constructs: Performance expectancy (PE), effort expectancy (EE), social influence (SI), self-efficacy (SE) and attitude towards using technology (ATUT) adapted from the original study of technology acceptance (Venkatesh et al. 2003); and system quality (SQ), information quality (IQ), information technology skill (ITS) and cost (C) adopted from various user-system behaviour and expectations models (Adnanh and Lee 2015; Min et al. 2003; 
Delone and McLean 2003). A total of nine hypotheses were generated to study the librarians' acceptance of Koha open source library information system using the OSIS model.

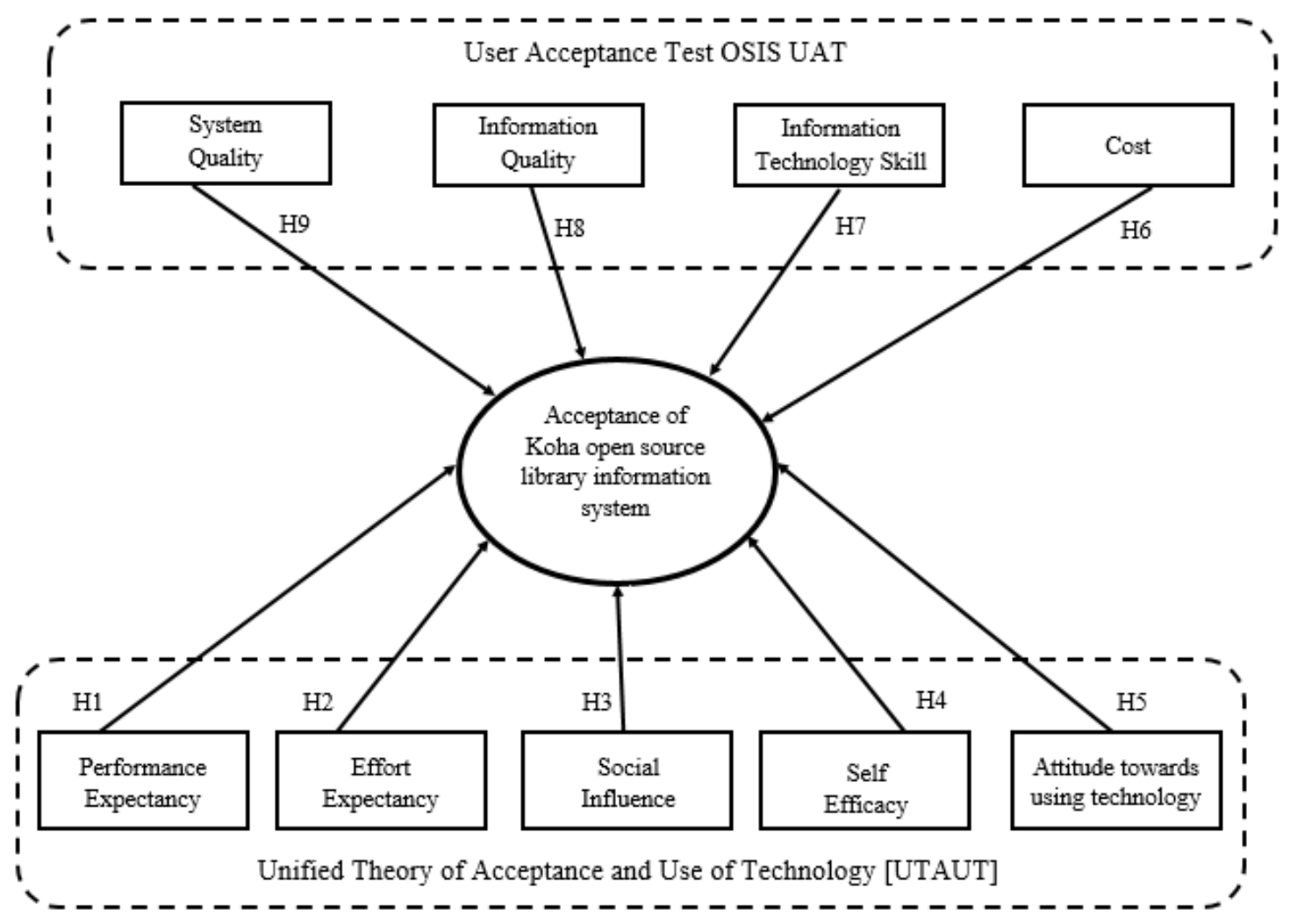

Figure 2: OSIS acceptance model

\section{Hypotheses Development \\ Performance Expectancy (PE)}

Performance expectancy refers to the degree to which an individual believes that using the system will help him/her to attain gains in job performance (Venkatesh et al. 2003). User's job performance in using an open source library system is measured based on system activities which provides benefits to the user's daily task. Usually, there is a significant direct effect of performance expectancy on user behaviour to use a technology (Ali and Sreenivasarao 2013; Anwar et al. 2012). Performance expectancy is a predictor and usefulness measurement tool for system based performance. Therefore, this assumption is assessed under the dimension of belief in the system usage, tasks accomplishment, tasks productivity and job effectiveness. Thus, it is assumed that performance expectancy will influence librarians' acceptance of an open source system and individual job performance:

H1: Performance expectancy positively influence librarian's acceptance of Koha open source library information system.

\section{Effort Expectancy (EE)}

Effort expectancy refers to the degree of ease associated with the use of the system under the dimension of system usage (Venkatesh et al. 2003; Ali and Sreenivasarao 2013). Evaluating the user and system interaction is indicated as effort expectancy and in this study it is assessed under the dimension of ease of use, system command and ease of learning to use the system. Thus, effort expectancy will influence librarians' acceptance of an open source system. 
H2: Effort expectancy positively influence librarian's acceptance of Koha open source library information system.

\section{Social Influence (SI)}

Social influence is defined as the degree to which an individual perceives the importance based on the belief of others on whether he/she should use the new system (Venkatesh et al. 2003; Gallego et al. 2008). This study identifies social influence as the influence of library association, professionals and top management on users' behavior. Therefore, it is assumed that higher level of social influence leads to higher level system acceptance. Thus, it is hypothesized:

H3: Social influence positively influence librarian's acceptance of Koha open source library information system.

\section{Self-Efficacy (SE)}

Individual skill and ability to perform a task is defined as self-efficacy which reflects users' confidence level (Venkatesh et al. 2003; Sundaravej 2010). In this study self-efficacy plays a vital role in building attitudes towards technology usage with the self-expertise, built-in system help and other available help features. The librarians' confidence, ability and belief in open source library information system will eventually reflect acceptance of open source technology. Thus, self-efficacy if hypothesized to have an influence on librarians' acceptance of open source system.

H4: Self-efficacy positively influence librarian's acceptance of Koha open source library information system.

\section{Attitude towards using technology (ATUT)}

Attitude is the individual's positive or negative feeling about performing the target behavior in using a system (Venkatesh et al. 2003). Attitude also reflects an individual's overall positive and negative perception reaction to using a system. In the UTAUT model, attitude has the highest influences on technology adoption and implementation. This study define attitude as the users' favour or disfavour, way of thinking and norm characteristics to use an open source library information system with the dimension of system friendliness, practice, exposure to open systems, impression of open systems and likelihood of system usage. Kim et al., (2005) found that prior use was a strong predictor of future technology use. Therefore, attitude resulting from system usage is likely to increase librarians' acceptance of a system. Hence, the formulated hypothesis is:

H5: Attitude towards using technology positively influence librarian's acceptance of Koha open source library information system.

\section{Cost (C)}

Cost is an important construct in the technology acceptance model and it refers to the amount of price or value added for money which has a positive influence on the technology adoption and implementation (Min et al. 2008; Bailey 2011; Adnanh and Lee 2015). This study defines cost as the price for an open source library information system, training and maintenance in relation to available budget within the domain of budget, ownership system and market value. The majority of the research in the use of technology posits cost as the most proximal antecedent of actual use. Thus, it is hypothesized that: 
H6: Cost positively influence the librarian's acceptance of Koha open source library information system.

\section{Information Technology Skill (ITS)}

Information technology skill refers to the skill gap which exists between the present information technology skill and the required skill to fulfil the organization needs and objectives (Adnanh and Lee 2015). In this study, the users' ICT knowledge, technical skill and computer skill when handling an open source library information system is measured using the dimension of technical use, ICT knowledge, ease to develop, ease to maintain, programming proficiency and open system competencies. Information technology skill resulting from system usage is likely to increase librarians' acceptance of system. Hence, the formulated hypothesis is:

H7: Information technology skill positively influence the librarian's acceptance of Koha open source library information system.

\section{Information Quality (IQ)}

Information Quality is the process of maximizing the value of organization information to assure the accuracy and real time information availability in the system (Lewis, 2002). Information quality reflects the true situation, implies mission task and situation at hand, availability in time of decisions, easily understandable and presentable information with level of detail and afforded adequate protection within the system (Lewis 1995). Min et al. (2008) referred to it as information satisfaction in their mobile commerce user study. The information quality for open source technology in this study refers to information that resides in a system, data standard and information organization. Information quality is evaluated using the dimension of data format, response upon faulty input, data recovery, accuracy of data searching, matching and mapping of data. Therefore, it is assumed that appropriate level of information quality leads to higher level system acceptance. Thus, it is hypothesized:

H8: Information quality positively influence the librarian's acceptance of Koha open source library information system.

\section{System Quality (SQ)}

System quality has positive influence on the acceptance of technology and is defined as the degree to which an individual believes that the system performs the task according to the needs of the users (Lewis 2002). Policy, standard stipulations and quality documentation are the initial remarks for system quality based on proprietary system approach and deployment (Lewis 1995). Min et al. (2003) referred to it as system satisfaction in their mobile commerce user study The technology has been transformed from proprietary based approach to open source technology scenario, therefore the evaluation for system quality has been diverted to elements defined in this study such as the interrelation and connectivity between system components and dependability, flow of a data process, reliability and portability. System quality is evaluated using system platform, integration, processing capacity, independent modules, respond time and system standard. Prior use is a strong predictor of future technology use. Therefore, attitude resulting from system usage is likely to increase librarians' acceptance of a system. Hence, the formulated hypothesis is:

H9: System quality positively influence the librarian's acceptance of Koha open source library information system. 


\section{METHOD}

\section{Data Collection Procedure}

A survey of university librarians' intention to use the Koha open source system was carried out from mid-June 2016 to mid-August 2016. The librarians were from five academic libraries in Malaysia which are Koha users and they agreed to participate in this study. The survey was conducted using printed questionnaire and distributed to librarians from the participating libraries. The inclusion criteria used for selecting respondents was that they must be Koha system users. The library management identified the respondents and a total of 254 questionnaires were was distributed. The questionnaire was derived from the literature, mainly from Sundaravej (2010) and Lewis (1995; 2002). A total of 245 complete and valid responses were collected $(96.45 \%$ response rate) for analysis.

A pre-test was conducted at 3 campus libraries (which were excluded from the final study) in June, 2016. A total of 30 respondents were given 7 days to complete the questionnaire. The result of the pre-test revealed that Cronbach's alpha for all 9 constructs was above the threshold of 0.7 , indicating high reliability. No items were removed and respondents did not raise any issues on the item clarity and suitability, causing the researcher to assume content and face validity.

\section{Variable and Measurement}

The measurement items of the constructs were adapted from various studies in the literature. The constructs of performance expectancy (PE), effort expectancy (EE), social influence (SI), self-efficacy (SE), attitude towards using technology(ATUT) were adapted from Venkatesh et al. (2003), system quality (SQ), information quality (IQ) were adapted from Delone and McLean (2002; 2003), cost (C) from Gallego et al. (2008), Galandere-Zile and Vinogradova (2005) and information technology skill (ITS) from Adnanh and Lee (2015). The measurement items of the constructs were adapted from Sundaraj (2010) and Lewis (1995; 2002). The measurement items were anchored on a five-point Likert scale ranging from 1- 'strongly disagree' to 5 - 'strongly agree'. There are a total of 61 items; 5 items for $\mathrm{PE}, 6$ items for EE, 6 items for ITS, 9 items for SQ, 7 items for IQ, 6 items for C, 6 items for SI, 4 items for SE, 7 items for ATUT and 5 items for ATUKOSLIS. Appendix 1 presents the variables, the measurement items used for this research and sources of the constructs.

\section{ANALYSIS AND RESULTS}

\section{Profile of the Respondents}

A total of five (5) public and private academic libraries in Malaysia, which have adopted Koha since 2014, were selected for this study. The demographic representation of the respondents ( $n=245)$ is shown in Table 2 . The majority of the respondents (55.9\%) were from a public university, while the remaining 44.1 percent were from 4 different private university libraries. There were less than 5 percent of young librarians, below 25 years and 23.3 percent who were above the age of 45 . It was reported that 71 percent of the respondents knew about Koha from other librarians. Most of them (67.4\%) had been using Koha between 1-5 years and 47.4 percent had received at least 1-5 hours of training on Koha 46.9 percent reported to have received more than 5 hours of training, while 5.7 percent reported they had received no training at all. 
Table 2: Profile of the Respondents ( $n=245)$

\begin{tabular}{l|l|r|r}
\hline \hline \multicolumn{2}{c|}{ Characteristic } & Frequency & Percentage (\%) \\
\hline \hline Institutional Library & Public Library & 137 & 55.9 \\
& Private Libraries & 108 & 44.1 \\
\hline \hline Gender & Male & 141 & 57.56 \\
& Female & 104 & 42.44 \\
\hline \hline Age & Less than 25 years old & 11 & 4.49 \\
& 25 - 35 years old & 105 & 42.86 \\
& 36 - 45 years old & 72 & 29.39 \\
& More than 45 years old & 57 & 23.26 \\
\hline \hline Knowledge about Koha from... & Internet & 20 & 8.16 \\
& Library Association & 27 & 11.02 \\
& Librarians & 174 & 71.02 \\
& Others & 24 & 9.80 \\
\hline \hline Koha usage duration & Less than 1 year & 59 & 24.08 \\
& 1 - 5 years & 165 & 67.35 \\
& More than 5 years & 21 & 8.57 \\
\hline \hline Koha training hours & 1 - 5 hours & 116 & 47.35 \\
& More than 5 hours & 115 & 46.94 \\
& None & 14 & 5.71 \\
\hline \hline
\end{tabular}

\section{Factors Affecting OSIS Acceptance}

Partial least square- structural equation modelling (PLS-SEM) is used to measure the relationships between the variables of the OSIS-UTAUT research model. The benefit of SEM is that it allows comprehensive and simultaneous analysis of a complex model with multiple independent and dependent variables (Gefen et al. 2000; Kline 2005). The OSIS-UTAUT model is analyzed using the SmartPLS Professional Version 3.0 software. There are two models; the measurement model and structural model in line with a two-staged analytical process (Hair et al. 2014). The reliability and validity of the instrument is tested in the measurement model. The structural model was examined to evaluate the hypothesis and to estimate path co-efficients. A bootstrapping mechanism using 500 re-sample was utilized to access the path coefficient significance and the loadings. Finally, the model fit was accessed using the predictive relevancy $\left(Q^{2}\right), R$ square, standardized root mean square residual (SRMR) and normal fit index (NFI) values.

\section{Measurement Model}

The measurement model measures both convergent and discriminant validity using the Fornell-Larcker criterion or cross validity method and reliability. The convergent validity was accessed by examining the loading of average variance extracted (AVE) and composite reliability (CR). The measure suggested that $A V E>0.5$ and $C R>0.7$ and the instrument constructs measurement of Cronbach alpha measure is above 0.7 (Hair et al. 2014). As shown in Table 3, the AVE was more than 0.5, and the CR and Cronbach alpha was more than 0.7. The Fornell and Larcker criterion is to compare the AVE with the squared correlations or, alternatively, compare the square root of the AVE with the correlations (Fornell and Larcker 1981). Table 3 shows that the square roots of the AVE (bolded) are all higher than the off-diagonal correlation values, suggesting there is sufficient discriminant validity. 
Zainab, A.M. et al.

Table 3: Assessment of Constructs Validity (Fornell-Larcker Criterion)

\begin{tabular}{|c|c|c|c|c|c|c|c|c|c|c|c|c|c|}
\hline Constructs & $\begin{array}{c}\text { Cronbach } \\
\text { Alpha } \\
(\alpha)\end{array}$ & $\begin{array}{l}\text { Composite } \\
\text { Reliability } \\
\text { (rho A) }\end{array}$ & AVE & ATUKOSLIS & ATUT & C & $\mathrm{EE}$ & IQ & ITS & PE & SE & SI & SQ \\
\hline $\begin{array}{l}\text { Acceptance } \\
\text { of Koha } \\
\text { OSLIS }\end{array}$ & 0.95 & 0.97 & 0.86 & 0.93 & & & & & & & & & \\
\hline $\begin{array}{l}\text { Attitude } \\
\text { Towards } \\
\text { Using } \\
\text { Technology }\end{array}$ & 0.94 & 0.95 & 0.80 & 0.87 & 0.89 & & & & & & & & \\
\hline Cost & 0.92 & 0.94 & 0.71 & 0.58 & 0.59 & 0.84 & & & & & & & \\
\hline $\begin{array}{l}\text { Effort } \\
\text { Expectancy }\end{array}$ & 0.91 & 0.93 & 0.70 & 0.71 & 0.72 & 0.53 & 0.84 & & & & & & \\
\hline $\begin{array}{l}\text { Information } \\
\text { Quality }\end{array}$ & 0.90 & 0.92 & 0.62 & 0.72 & 0.71 & 0.56 & 0.66 & 0.79 & & & & & \\
\hline $\begin{array}{l}\text { Information } \\
\text { Technology } \\
\text { Skill } \\
\end{array}$ & 0.87 & 0.90 & 0.65 & 0.53 & 0.54 & 0.43 & 0.62 & 0.60 & 0.81 & & & & \\
\hline $\begin{array}{l}\text { Performance } \\
\text { Expectancy }\end{array}$ & 0.91 & 0.94 & 0.79 & 0.73 & 0.74 & 0.53 & 0.75 & 0.67 & 0.56 & 0.89 & & & \\
\hline Self-Efficacy & 0.88 & 0.92 & 0.73 & 0.67 & 0.68 & 0.56 & 0.64 & 0.67 & 0.54 & 0.60 & 0.85 & & \\
\hline $\begin{array}{l}\text { Social } \\
\text { Influence }\end{array}$ & 0.89 & 0.91 & 0.64 & 0.72 & 0.72 & 0.58 & 0.72 & 0.67 & 0.55 & 0.66 & 0.63 & 0.80 & \\
\hline $\begin{array}{l}\text { System } \\
\text { Quality }\end{array}$ & 0.91 & 0.93 & 0.62 & 0.74 & 0.76 & 0.56 & 0.71 & 0.74 & 0.65 & 0.66 & 0.64 & 0.69 & 0.79 \\
\hline
\end{tabular}

Note: Value bold (diagonally) are the VAVE; the off diagonals are correlations; Cronbach's $\alpha>0.7 ;$ CR > 0.7; AVE > 0.5

The cross loadings are as shown in Table 4. The range for each construct are: Performance expectancy (0.872-0.925), effort expectancy (0.794-0.853), information technology skill (0.712-0.849), system quality $(0.764-0.813)$, information quality $(0.741-0.837)$, cost $(0.751$ $0.901)$, social influence $(0.716-0.876)$, self-efficacy $(0.823-0.888)$, attitude towards using technology (0.861-0.917) and acceptance of Koha open source library information system (0.913-0.941). The discriminant validity was accessed using the cross loadings. The cross loading table does not show any issue with discriminant validity. As a result, it was concluded that the measures used in this study exhibit sufficient validity and reliability.

Table 4: Cross Loading

\begin{tabular}{|l|c|c|c|c|c|c|c|c|c|c|}
\hline $\begin{array}{l}\text { Construct } \\
\text { Variable }\end{array}$ & PE & EE & ITS & SQ & IQ & C & SI & SE & ATUT & ATUKOSLIS \\
\hline PE1 & $\mathbf{0 . 8 3 9}$ & 0.586 & 0.396 & 0.507 & 0.556 & 0.469 & 0.514 & 0.492 & 0.576 & 0.584 \\
\hline PE2 & $\mathbf{0 . 9 0 6}$ & 0.638 & 0.502 & 0.604 & 0.604 & 0.457 & 0.587 & 0.528 & 0.657 & 0.666 \\
\hline PE3 & $\mathbf{0 . 9 2 5}$ & 0.715 & 0.559 & 0.634 & 0.623 & 0.459 & 0.622 & 0.560 & 0.692 & 0.680 \\
\hline PE5 & $\mathbf{0 . 8 7 2}$ & 0.698 & 0.499 & 0.590 & 0.591 & 0.505 & 0.617 & 0.544 & 0.675 & 0.655 \\
\hline EE6 & 0.686 & $\mathbf{0 . 8 5 0}$ & 0.572 & 0.647 & 0.555 & 0.390 & 0.605 & 0.553 & 0.630 & 0.606 \\
\hline EE7 & 0.633 & $\mathbf{0 . 8 5 3}$ & 0.503 & 0.589 & 0.564 & 0.426 & 0.580 & 0.562 & 0.608 & 0.615 \\
\hline EE8 & 0.630 & $\mathbf{0 . 7 9 4}$ & 0.504 & 0.560 & 0.561 & 0.432 & 0.633 & 0.501 & 0.625 & 0.626 \\
\hline EE9 & 0.662 & $\mathbf{0 . 8 4 1}$ & 0.526 & 0.561 & 0.535 & 0.489 & 0.634 & 0.564 & 0.605 & 0.590 \\
\hline EE10 & 0.503 & $\mathbf{0 . 8 1 4}$ & 0.487 & 0.565 & 0.520 & 0.454 & 0.527 & 0.494 & 0.518 & 0.503 \\
\hline EE11 & 0.600 & $\mathbf{0 . 8 4 7}$ & 0.500 & 0.611 & 0.540 & 0.460 & 0.601 & 0.520 & 0.594 & 0.616 \\
\hline ITS13 & 0.442 & 0.484 & $\mathbf{0 . 7 4 2}$ & 0.522 & 0.476 & 0.379 & 0.415 & 0.446 & 0.434 & 0.412 \\
\hline ITS14 & 0.429 & 0.513 & $\mathbf{0 . 8 4 9}$ & 0.516 & 0.485 & 0.308 & 0.447 & 0.406 & 0.464 & 0.468 \\
\hline ITS15 & 0.515 & 0.514 & $\mathbf{0 . 8 7 6}$ & 0.559 & 0.538 & 0.431 & 0.460 & 0.444 & 0.487 & 0.505 \\
\hline ITS16 & 0.263 & 0.328 & $\mathbf{0 . 7 1 2}$ & 0.386 & 0.340 & 0.218 & 0.319 & 0.429 & 0.237 & 0.233 \\
\hline ITS17 & 0.517 & 0.597 & $\mathbf{0 . 8 3 6}$ & 0.602 & 0.502 & 0.360 & 0.524 & 0.476 & 0.482 & 0.442 \\
\hline SQ18 & 0.574 & 0.558 & 0.509 & $\mathbf{0 . 7 4 4}$ & 0.604 & 0.327 & 0.493 & 0.501 & 0.636 & 0.623 \\
\hline SQ19 & 0.567 & 0.600 & 0.500 & $\mathbf{0 . 7 7 2}$ & 0.522 & 0.418 & 0.553 & 0.459 & 0.594 & 0.578 \\
\hline
\end{tabular}




\begin{tabular}{|c|c|c|c|c|c|c|c|c|c|c|}
\hline \multicolumn{11}{|c|}{ Table 4 continued } \\
\hline SQ20 & 0.443 & 0.513 & 0.499 & 0.772 & 0.560 & 0.490 & 0.530 & 0.555 & 0.557 & 0.547 \\
\hline SQ21 & 0.460 & 0.508 & 0.475 & 0.806 & 0.603 & 0.481 & 0.552 & 0.467 & 0.617 & 0.620 \\
\hline SQ22 & 0.526 & 0.559 & 0.536 & 0.809 & 0.614 & 0.430 & 0.574 & 0.583 & 0.631 & 0.636 \\
\hline SQ23 & 0.549 & 0.580 & 0.528 & 0.829 & 0.613 & 0.434 & 0.543 & 0.497 & 0.609 & 0.583 \\
\hline SQ24 & 0.561 & 0.588 & 0.554 & 0.813 & 0.601 & 0.512 & 0.561 & 0.511 & 0.595 & 0.595 \\
\hline SQ25 & 0.484 & 0.555 & 0.512 & 0.764 & 0.553 & 0.475 & 0.508 & 0.488 & 0.502 & 0.491 \\
\hline IQ27 & 0.556 & 0.499 & 0.494 & 0.595 & 0.756 & 0.545 & 0.530 & 0.505 & 0.541 & 0.580 \\
\hline IQ28 & 0.473 & 0.477 & 0.547 & 0.592 & 0.741 & 0.463 & 0.442 & 0.457 & 0.485 & 0.477 \\
\hline IQ29 & 0.492 & 0.464 & 0.429 & 0.539 & 0.793 & 0.398 & 0.442 & 0.532 & 0.487 & 0.514 \\
\hline IQ30 & 0.570 & 0.585 & 0.445 & 0.565 & 0.772 & 0.405 & 0.547 & 0.506 & 0.592 & 0.593 \\
\hline IQ31 & 0.489 & 0.458 & 0.423 & 0.543 & 0.761 & 0.387 & 0.522 & 0.530 & 0.573 & 0.580 \\
\hline IQ32 & 0.544 & 0.544 & 0.467 & 0.579 & 0.837 & 0.438 & 0.531 & 0.588 & 0.551 & 0.554 \\
\hline IQ33 & 0.548 & 0.559 & 0.464 & 0.657 & 0.831 & 0.440 & 0.633 & 0.553 & 0.645 & 0.631 \\
\hline C34 & 0.404 & 0.365 & 0.385 & 0.406 & 0.473 & 0.751 & 0.396 & 0.477 & 0.415 & 0.432 \\
\hline C35 & 0.530 & 0.504 & 0.387 & 0.546 & 0.508 & 0.887 & 0.505 & 0.490 & 0.532 & 0.538 \\
\hline C36 & 0.460 & 0.450 & 0.332 & 0.459 & 0.502 & 0.858 & 0.481 & 0.490 & 0.496 & 0.492 \\
\hline C37 & 0.417 & 0.405 & 0.361 & 0.457 & 0.427 & 0.833 & 0.445 & 0.447 & 0.460 & 0.439 \\
\hline C38 & 0.450 & 0.468 & 0.370 & 0.484 & 0.450 & 0.901 & 0.492 & 0.457 & 0.525 & 0.500 \\
\hline C39 & 0.408 & 0.457 & 0.351 & 0.470 & 0.455 & 0.798 & 0.567 & 0.478 & 0.489 & 0.485 \\
\hline SI40 & 0.550 & 0.625 & 0.534 & 0.568 & 0.534 & 0.405 & 0.784 & 0.491 & 0.592 & 0.518 \\
\hline SI41 & 0.570 & 0.611 & 0.527 & 0.625 & 0.613 & 0.532 & 0.812 & 0.558 & 0.636 & 0.643 \\
\hline SI42 & 0.481 & 0.585 & 0.454 & 0.570 & 0.513 & 0.452 & 0.835 & 0.510 & 0.557 & 0.593 \\
\hline SI43 & 0.507 & 0.554 & 0.387 & 0.541 & 0.543 & 0.474 & 0.876 & 0.518 & 0.590 & 0.601 \\
\hline SI44 & 0.514 & 0.543 & 0.333 & 0.415 & 0.441 & 0.355 & 0.716 & 0.365 & 0.476 & 0.496 \\
\hline SI45 & 0.557 & 0.527 & 0.378 & 0.540 & 0.550 & 0.515 & 0.762 & 0.545 & 0.600 & 0.585 \\
\hline SE46 & 0.536 & 0.588 & 0.436 & 0.583 & 0.577 & 0.479 & 0.554 & 0.851 & 0.634 & 0.599 \\
\hline SE47 & 0.474 & 0.532 & 0.486 & 0.532 & 0.578 & 0.461 & 0.494 & 0.862 & 0.559 & 0.565 \\
\hline SE48 & 0.523 & 0.539 & 0.466 & 0.542 & 0.528 & 0.515 & 0.571 & 0.888 & 0.585 & 0.571 \\
\hline SE49 & 0.520 & 0.526 & 0.464 & 0.546 & 0.611 & 0.474 & 0.528 & 0.823 & 0.538 & 0.550 \\
\hline ATUT50 & 0.700 & 0.657 & 0.510 & 0.666 & 0.688 & 0.579 & 0.665 & 0.624 & 0.896 & 0.786 \\
\hline ATUT51 & 0.606 & 0.667 & 0.487 & 0.637 & 0.558 & 0.542 & 0.640 & 0.581 & 0.861 & 0.713 \\
\hline ATUT52 & 0.680 & 0.649 & 0.525 & 0.721 & 0.619 & 0.475 & 0.668 & 0.577 & 0.880 & 0.793 \\
\hline ATUT55 & 0.624 & 0.600 & 0.442 & 0.650 & 0.644 & 0.468 & 0.609 & 0.603 & 0.902 & 0.779 \\
\hline ATUT56 & 0.665 & 0.631 & 0.452 & 0.687 & 0.651 & 0.532 & 0.638 & 0.636 & 0.917 & 0.803 \\
\hline ATUKOSLIS57 & 0.691 & 0.666 & 0.500 & 0.651 & 0.649 & 0.507 & 0.647 & 0.639 & 0.767 & 0.918 \\
\hline ATUKOSLIS58 & 0.664 & 0.677 & 0.492 & 0.676 & 0.662 & 0.517 & 0.680 & 0.620 & 0.804 & 0.941 \\
\hline ATUKOSLIS59 & 0.669 & 0.660 & 0.490 & 0.737 & 0.672 & 0.562 & 0.706 & 0.618 & 0.815 & 0.913 \\
\hline ATUKOSLIS60 & 0.686 & 0.658 & 0.484 & 0.707 & 0.671 & 0.560 & 0.661 & 0.624 & 0.818 & 0.943 \\
\hline ATUKOSLIS61 & 0.675 & 0.643 & 0.494 & 0.673 & 0.676 & 0.516 & 0.641 & 0.593 & 0.822 & 0.914 \\
\hline
\end{tabular}

\section{Structural Model}

The hypotheses developed for this study were tested by running the bootstrapping procedure with a resample of 500, as suggested by Hair et al. (2014). The result is presented in Table 5. The accuracy level of $90 \%, 95 \%$ and $99 \%$ are used to obtained high accuracy with large samples (Hair et al. 2014). Large sample will be equal and tend to produce a better estimation of the population. Therefore, as predicted, the following factors related to open source Koha technology acceptance: attitude towards using technology (path coefficient $=0.642, t=8.02, p<0.01$ ), performance expectancy ( ath coefficient $=0.193, t=1.713, p<$ 0.05 ), system quality (path coefficient $=0.165, t=1.734, p<0.05$ ), social influence (path coefficient $=0.168, \mathrm{t}=1.308, \mathrm{p}<0.10$ ) and information quality (path coefficient $=0.170, \mathrm{t}=$ 1.287, $\mathrm{p}<0.10$ ). These findings support $\mathrm{H} 1, \mathrm{H} 3, \mathrm{H} 5, \mathrm{H} 8$ and $\mathrm{H} 9$.

The model's predictive relevance was assessed by utilizing the blindfolding procedure. Blindfolding using the $Q^{2}$ value is to determine the predictive relevancy of an empirical path (DeCoster 1998), in this case the OSIS-UTAUT model's ability to predict new observations accurately. The model possesses predictive relevance for specific endogenous constructs if the $Q^{2}$ value amounts to greater than 0 (Hair et al. 2014). In this study the $Q^{2}$ value is 0.6333 $(>0)$, indicating an adequate predictive relevance is inherent in the model. 
Table 5: Hypothesis Testing

\begin{tabular}{|c|c|c|c|c|c|}
\hline Hypothesis & Relationship & $\begin{array}{c}\text { Path } \\
\text { coefficient }\end{array}$ & $t$-value & p-value & Decision \\
\hline $\mathrm{H} 1$ & $\mathrm{PE} \rightarrow$ ATUKOSLIS & 0.193 & $1.713 * *$ & 0.044 & Supported \\
\hline $\mathrm{H} 2$ & EE $\rightarrow$ ATUKOSLIS & 0.135 & 0.619 & 0.268 & Not Supported \\
\hline $\mathrm{H} 3$ & $\mathrm{SI} \rightarrow$ ATUKOSLIS & 0.168 & $1.308 *$ & 0.096 & Supported \\
\hline $\mathrm{H} 4$ & SE $\rightarrow$ ATUKOSLIS & 0.105 & 0.844 & 0.199 & Not Supported \\
\hline H5 & ATUT $\rightarrow$ ATUKOSLIS & 0.642 & $8.027 * * *$ & 0.000 & Supported \\
\hline $\mathrm{H} 6$ & $C \rightarrow$ ATUKOSLIS & 0.090 & 0.415 & 0.339 & Not Supported \\
\hline $\mathrm{H7}$ & ITS $\rightarrow$ ATUKOSLIS & 0.025 & 0.877 & 0.190 & Not Supported \\
\hline $\mathrm{H} 8$ & IQ $\rightarrow$ ATUKOSLIS & 0.170 & $1.287 *$ & 0.099 & Supported \\
\hline H9 & SQ $\rightarrow$ ATUKOSLIS & 0.165 & $1.734^{* *}$ & 0.042 & Supported \\
\hline
\end{tabular}

Note: Confidence level (one tailed): $90 \%\left({ }^{*}\right) \mathrm{t}>1.28, \mathrm{p}<0.10 ; 95 \%\left({ }^{* *}\right) \mathrm{t}>1.645, \mathrm{p}<0.05 ; 99 \%\left({ }^{* *}\right)$ $\mathrm{t}>2.33 ; \mathrm{p}<0.01$ path coefficient $>0.1$

The amount of variance in the dependent latent variable is explained by the independent latent variables using the estimation of $R^{2}$ value. Since 5 factors are significant and 4 are insignificant, the adjusted $R^{2}$ is 0.789 ( $\left.0.79 \%\right)$. The adjusted $R^{2}$ is above $75 \%$, therefore the adjusted $R^{2}$ is insignificant for technology acceptance of OSIS-UTAUT model.

The SRMR is the goodness of fit measure for PLS-SEM. The SRMR obtained is 0.057 , is measuring the observed and expected correlations as an absolute measure of model fit with the value less than 0.10 or of 0.08 is considered a good fit (Hair et al. 2014). The NFI is the first fit measure in structural equation modelling by Bentler and Bonett (1980). The NFI above 0.5 and closer to 1 is considered the better to model fit (Lohmöller 1989). The value obtained is 0.725 and is above 0.5 , therefore the model fit is acceptable.

The OSIS-UTAUT technology acceptance model in Figure 3 illustrates the one tailed significance hypotheses, values of $R^{2}$ and path coefficient. The inclusion of new constructs, system quality, information quality and information technology skill, have revealed an acceptable OSIS-UTAUT model.

The model reflects the acceptance of Koha OSLIS in Malaysian public and private universities. The librarians' acceptance of the open source system strongly supports the open source technology and Koha in the library profession.

Initially there were 61 items used in the survey, however the final analysis removed 7 items to improve model fit. Therefore 56 items from the final OSIS-UTAUT model. The cost, information technology skill, self- efficacy and effort expectancy constructs do not contribute to the librarians' acceptance of Koha open source library information system. 


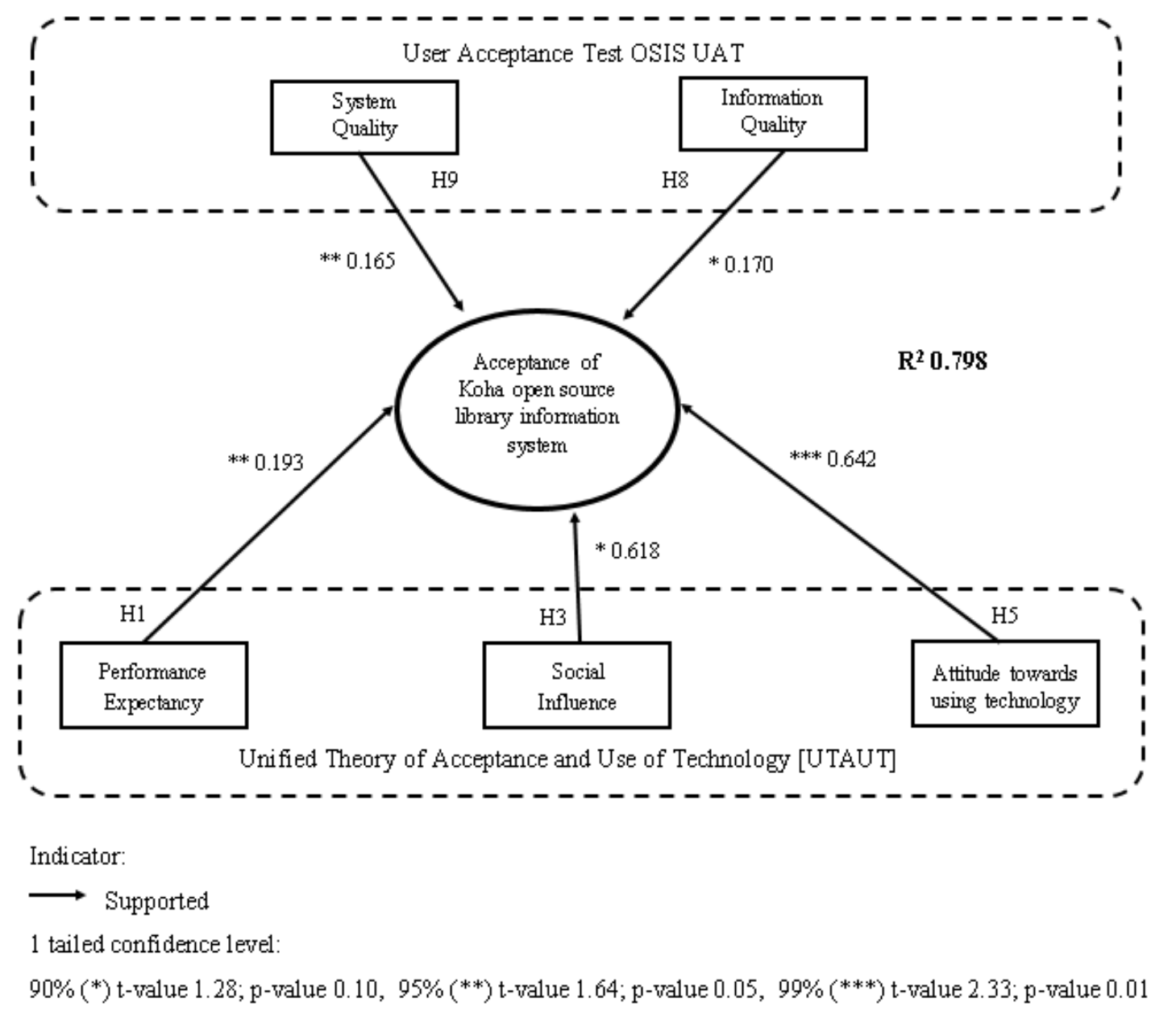

Figure 3: OSIS-UTAUT Technology Acceptance Model with Results

\section{CONCLUSION}

This study contributes empirical findings to understanding and measuring user-centered acceptance of open source technology in a country that is determined to lead in technology adoption and use. Malaysian university librarians are reported to be in the early stages of open source adoption, thus the OSIS-UTAUT model developed in this study to model the predictors of librarians' acceptance of Koha OSIS is the way forward to gain a better understanding of the factors that affect librarians intention which may further increase the adoption and use of open source library information systems. It is important to know the predictors to enable better control of the predictors and changes or enhancements may be made early in the process of adoption so system success is increased. Understanding the determinants for librarians' acceptance of open source system can assist in boosting the open source technology for the library market. Lack of user acceptance can lead to loss of money for the organization and if users of a system create resistance, the organization has to change their behaviour so that they may be inclined to use the technology for the benefit of the organization (Hwang, Al-Arabiat and Shin 2016).

With reference to the theoretical contribution, the findings provide adequate evidence of the validity of the UTAUT model in the context of the acceptance of Koha open source library information system in public and private university libraries in Malaysia. Removing 
facilitating conditions from the model on the basis of Ventakesh et al. (2008) argument that it has limitation in predicting behavior, also supported by findings from Ain, Kaur and Waheed (2016), did not have an effect on the model fit of the OSIS-UTAUT model. Extending the original UTAUT model to include system quality, information quality and information technology skill has shown to be sound and holistically impact the measurement of open source technology acceptance, including both behavioral and functional aspects. Finally, the actual acceptance was tested by combining the predictors from management model (UTAUT) and information system model (UAT) (Delone and McLean 2002) of open source system acceptance whereas previous studies (Adnanh and Lee 2015; Vimal Kumar and Jasimudeen2012; Zhussupova and Rahman 2011; Lewis 2002) focus on net benefits without measuring the users' acceptance. The main contribution is in modifying UTAUT for the librarians' open source technology acceptance and use context. By doing so, this research extends the generalizability of UTAUT from an organizational to a direct users' (librarians') context. Furthermore, this study also extends the previous research of Venkatesh et al. (2003) and Delone and McLean (2002) that tested the model on proprietary library system settings in Malaysian universities and suggested researchers to measure the users' acceptance econometrically for more adoption and implementation with robust findings. Users' acceptance is the powerful decision of the technology acceptance in an organization. The decision of adoption and implementation rely solely on the user acceptance and usage rate of a system.

As for the practical implications, the results of this study offer suggestions to library management on how to improve the library operations and services with regards open source library system adoption and implementation i.e. library users must be willingly use the Koha system without interruption, welcome the suggestion to continuity of Koha usage and enhance the system according to the users need. The system developers must focus on the librarian's criteria on information quality of data and information focused on accuracy and standards which reside in the system. The information quality criteria has a large impact on librarians' acceptance which will leads to adoption and implementation. The system quality is accepted based on capabilities and functionalities with user friendliness and service oriented functionalities (integration, system platform, processing capacity, independent modules, response time, and library system standard and gateway protocol). The study also reveals that librarians' performance expectancy increases according to the system usage (useful system, task accomplished quickly, task productivity and job effectiveness). Rahim (2009) had reported that the libraries in Malaysia have not met the full potential of open source technology adoption and implementation. Sadly, this study further ascertains that almost a decade later the situation has not improved much. It is hoped that the constructs examined in this study shall help developers and system users to understand and control the main drivers that can influence open source system acceptance among Malaysians.

\section{LIMITATION AND FUTURE RESEARCH}

A number of limitation are inherent in technology acceptance research. First, this research is limited to librarians in public and private university libraries in Malaysia, which makes generalization to a larger context of different cultural and national backgrounds difficult. The proposed research model attempted to measure the librarians' acceptance of positive stimuli such as attitude, social influence, information quality, systems quality and performance expectancy. Further research is needed to measure the reluctant acceptance of librarians in negative stimuli, such as resistant to accept and change from proprietary 
system to open source technology system. Another limitation is pertaining to the selfreported survey questionnaire. It is suggested that further work is needed with a qualitative or mixed method approach for a comprehensive interpretation of librarians' acceptance of open source technology system for adoption and implementation. Finally, it is believed that the understanding of this research results might be altered when librarians' experience of using the system increases. As such a longitudinal study may shed more evidences on the actual usage of OSIS in time.

\section{ACKNOWLEDGEMENT}

This study was financed by University of Malaya Grant PG144-2015B

\section{REFERENCES}

Abu Bakar, A., Rahmad, F., Mohd Amin, Z., Mustaffar, M.Y. and Bunawan, A.P. 2015. What more can you do with Koha? TINTA, Vol. 24, no. 5: 34-43.

Adnanh and Lee N. 2015. Preliminary study on open source software implementation in the Malaysian public sector. IEEE Transactions on Electronics, Information and System, Vol.136, no.12: 1742-1745.

Ain, N., Kaur, K., and Waheed, M. 2016. The influence of learning value on learning management system use: An extension of UTAUT2. Information Development, Vol.32, no.5: 1306-1321.

Ali, A. and Sreenivasarao, V. 2013. A case study of acceptance and use of electronic library services in university based on SO-UTAUT model. Innovative Research in Computer and Communication Engineering, Vol.1, no.4: 903-911.

Anwar, N., Masrek, M.N., and Rambli, Y.R. 2012. Visitor management system by applying the model of UTAUT. In 2012 IEEE Symposium on Business, Engineering and Industrial Applications (pp. 223-228). IEEE.

Bailey, P. 2011. How library management systems can demonstrate value for money from information and library services. Business Information Review, Vol.28, no 2:119-125.

Bentler, P.M. and Bonett D.G. 1980. Significance tests and goodness-of-fit in the analysis of covariance structures. Psychological Bulletin, Vol.88, no.3: 588-600.

Cassell, M. 2008. Why governments innovate: adoption and implementation of open source software by four European cities. Public Management, Vol.11, no.2: 193-213.

Chudnoy, D. 1999. Open source software: The future of library systems? Library Journal, Vol.124, no.13: 40-43.

DeCoster, J. 1998. Overview of factor analysis. Available at: http://www.stathelp.com/notes.html.

DeLone, W.H. and McLean, E.R. 2002. Information systems success revisited. In Proceedings of the $35^{\text {th }}$ Hawaii International Conference on System Science (pp.238-249), IEEE Computer Society Press.

Delone, W.H. and McLean, E.R. 2003. The DeLone and McLean model of information systems success: A ten-year update. Management Information Systems, Vol.19, no.4: 9-30.

Dulle, F.W. and Minishi-Majanja, M.K. 2011. The suitability of the Unified Theory of Acceptance and Use of Technology (UTAUT) model in open access adoption studies. Information Development, Vol.27, no.1: 32-45.

Eckhardt, A., Laumer, S. and Weitzel, T. 2009. Who influences whom? Analyzing workplace referents' social influence on IT adoption and non-adoption. Information Technology, Vol.24, no.1: 11-24. 
Edem, M.B. 2016. Adoption of software packages in university libraries in Nigeria. Library Philosophy and Practice, no.1342. Available at: http:// digitalcommons.unl.edu/libphilprac/1342.

Fornell, C. and Larcker, D.F. 1981. Evaluating structural equation models with unobservable variables and measurement error. Marketing Research, Vol.18, no1: 39-50.

Galandere-Zile, I. and Vinogradova, V. 2005. Where is the border between an information system and a knowledge management system? Managing Global Transitions, Vol.3, no2: $179-196$.

Gallego, M.D., Luna, P. and Bueno, S. 2008. User acceptance model of open source software. Computers in Human Behavior, Vol.24, no.5: 2199-2216.

Gefen, D., Straub, D.W. and Boudreau, M-C. 2000. Structural equation modeling and regression: Guidelines for research practice. Communications of the Association for Information Systems, Vol.4, no.7: 1-77.

Gireesh Kumar, T.K. and Jayapradeep, M. 2015. Perceptions of LIS professionals on open source integrated library system and adoptability of Koha over LibSys in India. Information Dissemination and Technology, Vol. 5, no 2: 100-105.

Gireesh Kumar, T.K. 2016. Embracing open source software for library automation: A feasibility study based on selected libraries in South India. In $61^{\text {st }}$ ILA International Conference Proceedings on Sustaining the Excellence: Transforming Libraries through Technology, Innovation and Value Added Services in Google Era (pp. 84-91). Saurashtra University Library, New Delhi.

Hair, J.F., Henseler, J., Dijkstra, T.K. and Sarstedt, M. 2014. Common beliefs and reality about partial least squares: Comments on Rönkkö and Evermann. Organizational Research Methods, Vol.7, no.2: 182-209.

Heeks, R. 2002. Information systems and developing countries: Failure, success, and local improvisations. Information Society, Vol.18, no.2: 101-112.

Hwang, Y., Al-Arabiat, M. and Shin, D.H. 2016. Understanding technology acceptance in a mandatory environment: A literature review. Information Development, Vol.32, no.4: 1266-1283.

Jaffe, L.D. and Careaga, G. 2007. Standing up for open source. Library Philosophy and Practice, Vol.9, no.2: 21.

Jayawardena, S. and Dias, G. 2011. Free and open source software for public sector enterprise applications in Sri Lanka. In Proceedings of the $2^{\text {nd }}$ International Conference on Information Management and Evaluation (pp. 239-252). Academic Publishing International Limited.

Johnston, K., Begg, S., and Tanner, M. 2013. Exploring the factors influencing the adoption of open source software in Western Cape schools. Education and Development using Information and Communication Technology, Vol.9, no.2: 64.

Kampa, R.K. 2018. Opening to open source: Analysing the awareness and use of open source integrated library system by LIS professionals in India, Global Knowledge, Memory and Communication. Global Knowledge, Memory and Communication, Vol. 67, no.4/5: 332-348.

Kim, S.S., Malhotra, N.K., and Narasimhan, S. 2005. Two competing perspectives on automatic use: a theoretical and empirical comparison. Information Systems Research, Vol.16, no.4: 418-432.

Kline, R.B. 2005. Principles and Practice of Structural Equation Modeling, Guildford, New York.

Lewis, J.R. 1995. IBM computer usability satisfaction questionnaires: psychometric evaluation and instructions for use. International Journal of Human-Computer Interaction, Vol.7, no.1: 57-78. 
Lewis, J.R. 2002. Psychometric evaluation of the PSSUQ using data from five years of usability studies. International Journal of Human-Computer Interaction, Vol.14, no.3-4: 463-488.

Lohmöller, J-B. 1989. Latent Variable Path Modeling with Partial Least Squares, Physica, Heidelberg, Germany.

Madhusudhan, M., and Singh, V. 2016. Integrated library management systems: comparative analysis of Koha, Libsys, NewGenLib, and Virtua. Electronic Library, Vol.34, no.2: 223-249.

MAMPU. 2016. Open source Implementation Guidelines: 1-77. Available at: http://www.mampu.gov.my/images/agensikerajaan/perkhidmatan/OSSImplementati on-Guideline.pdf.

Meissonier, R., and Houze, E. 2010. Attitude, involvement and participation in business open source software projects: An empirical analysis of developers' behaviours. Paper presented at the International Conference on Innovation, Engineering Management and Technology (ICIEMT)-WASET, 26-28 May, at Tokyo, Japan.

Min, Q., Ji, S., and Qu, G. 2008. Mobile commerce user acceptance study in China: a revised UTAUT model. Tsinghua Science \& Technology, Vol. 13, no. 3: 257-264.

Oyelude, A.A. 2016. Open source software for library systems - 2. Library Hi Tech News, Vol.33, no.90: 10-13.

Rafiq, M., and Ameen, K. 2009. Issues and lessons learned in open source software adoption in Pakistani libraries. Electronic Library, Vol.7, no.4: 601-610.

Rahim, A., Zairah, N., and Alias, R.A. 2006. Open source software appropriation in Malaysian public sector. In Proceedings of the Postgraduate Annual Research Seminar, Department of Information Systems (pp. 1-71). Universiti Teknologi Malaysia.

Rahim, N.Z.A., and Zairah, N. 2009. Multiple perspectives of open source software appropriation in Malaysian public sector (Doctoral dissertation, Universiti Teknologi Malaysia).

Rao, M. 2014. Library Automation: Why and How? National Conference on Management of Modern Libraries, Manipal, 21-22 February, 2014.

Raza, A., and Capretz, L.F. 2012. Do open source software developers listen to their users? First Monday, Vol. 17, no.3. Available at: doi:10.5210/fm.v17i3.3640.

Riewe, L.M. 2008. Survey of open source integrated library systems. (Master Thesis, San Jose State University). Available at: http://scholarworks.sjsu.edu/etd_theses/3481.

Singh, V. 2014. Expectations versus experiences: Librarians using open source integrated library systems. Electronic Library, Vol.32, no.5: 688-709.

Singh, V. 2017. Open source software use in libraries: Implications for social justice? Qualitative and Quantitative Methods in Libraries, Special Issue: Social Justice, Social Inclusion: 59-68.

Sundaravej, T. 2010. Empirical validation of unified theory of acceptance and use of technology model. Global Information Technology Management, Vol.13, no.1: 5-27.

Tella, A., and Oladeji, T. I. 2017. Empirical investigation on impact of Koha on library services in selected academic libraries in Nigeria. Annals of Library and Information Studies, Vol.64, no.2: 113-115.

Todd, C.R. 2018. Librarian as data migrator: a functional pathway from Millennium to Koha, Digital Library Perspectives, Vol.34, no. 1: 60-69.

Vimal Kumar, V., and Jasimudeen, S. 2012. Adoption and user perceptions of Koha library management system in India. Annals of Library and Information Studies, Vol.59, no.4: 223-230.

Venkatesh, V., Morris, M.G., Davis, G.B., and Davis, F.D. 2003. User acceptance of information technology: Toward a unified view. MIS Quarterly, Vol.27, no.3: 425-478.

Venkatesh, V., Brown, S.A., Maruping, L.M., and Bala, H. 2008. Predicting different conceptualizations of system use: The competing roles of behavioral intention, 
Zainab, A.M. et al.

facilitating conditions and behavioral expectation. MIS Quarterly, Vol.32, no.3: 483502.

Zainab, A.M., Kiran, K., Karim, N.H.A., and Sukmawati, M. 2018. UTAUT'S performance consistency: Empirical evidence from a library management system. Malaysian Journal of Library \& Information Science, Vol.23, no.1: 17-32.

Zhussupova, A., and Rahman, A.A. 2011. Open source software adoption in public organizations of Kazakhstan. Paper presented at the 2011 IEEE Conference on Open Systems (ICOS). Available at: doi:10.1109/ICOS.2011.6079306. 


\section{APPENDIX 1}

Construct, Indicator Variable and Items on the questionnaire

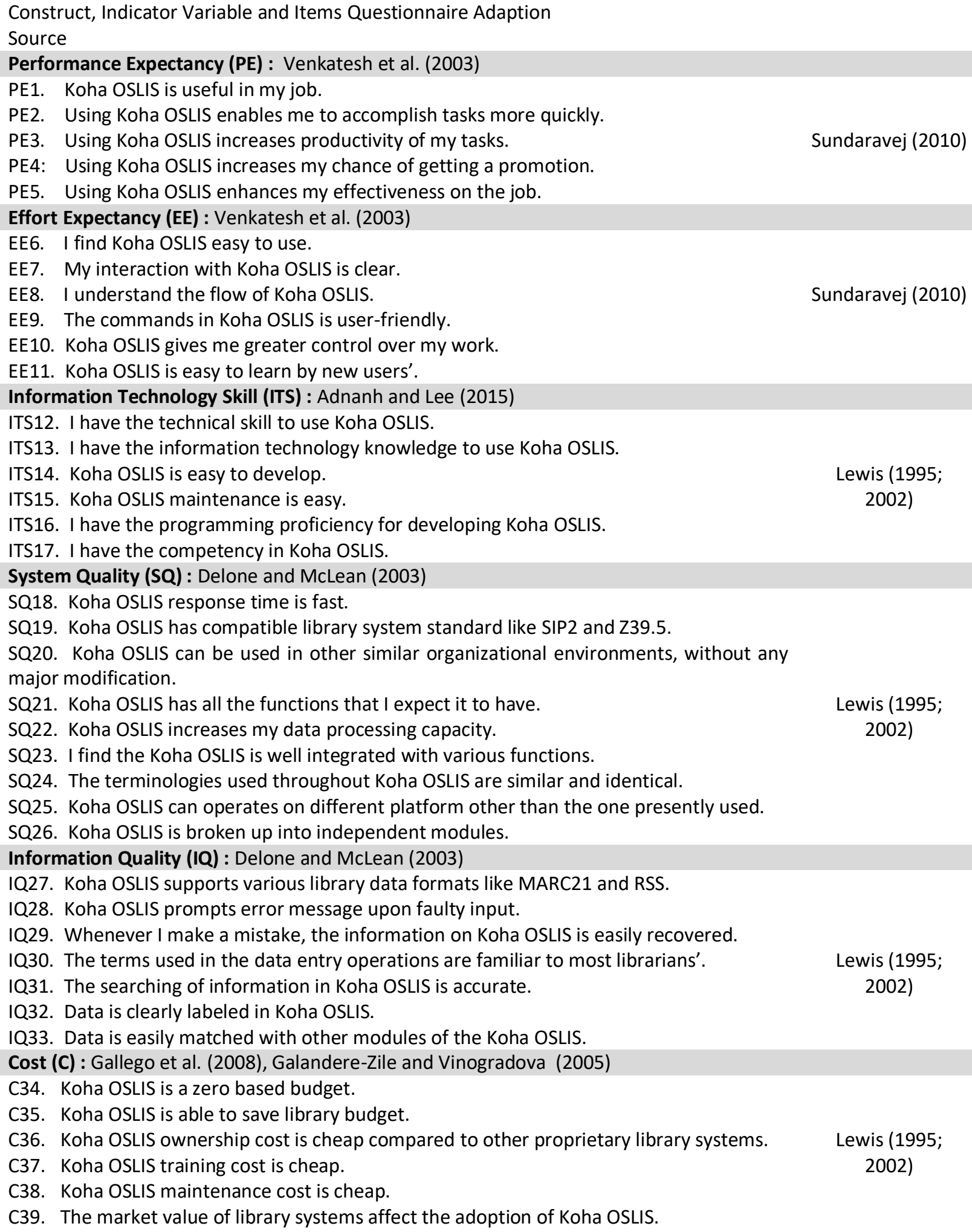

SQ23. I find the Koha OSLIS is well integrated with various functions.

SQ24. The terminologies used throughout Koha OSLIS are similar and identical.

SQ25. Koha OSLIS can operates on different platform other than the one presently used.

SQ26. Koha OSLIS is broken up into independent modules.

Information Quality (IQ) : Delone and McLean (2003)

IQ27. Koha OSLIS supports various library data formats like MARC21 and RSS.

IQ28. Koha OSLIS prompts error message upon faulty input.

IQ29. Whenever I make a mistake, the information on Koha OSLIS is easily recovered.

IQ30. The terms used in the data entry operations are familiar to most librarians'.

IQ31. The searching of information in Koha OSLIS is accurate.

IQ32. Data is clearly labeled in Koha OSLIS.

IQ33. Data is easily matched with other modules of the Koha OSLIS.

Cost (C) : Gallego et al. (2008), Galandere-Zile and Vinogradova (2005)

C34. Koha OSLIS is a zero based budget.

C35. Koha OSLIS is able to save library budget.

C36. Koha OSLIS ownership cost is cheap compared to other proprietary library systems.

C37. Koha OSLIS training cost is cheap.

C38. Koha OSLIS maintenance cost is cheap.

C39. The market value of library systems affect the adoption of Koha OSLIS. 
Social Influence (SI) : Venkatesh et al. (2003)

SI40. The Information Technology personnel influence my behavior on the deployment of Koha OSLIS.

SI41. The library association think that the library professionals should use Koha OSLIS. Sundaravej (2010)

SI42. People who influence my behavior at work think that I should use Koha OSLIS.

SI43. People who are important to me at work think that I should use Koha OSLIS.

SI44. The top management supports the adoption of Koha OSLIS.

SI45. Overall, the library professionals have supported the use of Koha OSLIS.

Self-Efficacy (SE) : Venkatesh et al. (2003)

SE46. I can complete a job or task using Koha OSLIS, even when there is no one around to tell me what to do.

SE47. I can complete a job or task using Koha OSLIS, despite problems arising.

SE48. I can complete a job or task using Koha OSLIS, regardless of the amount of time that I

have.

SE49. I can complete a job or task using Koha OSLIS, if the system has built-in help facility

for assistance.

Attitude Towards Using Technology (ATUT) : Venkatesh et al. (2003)

ATUT50. Using Koha OSLIS is a good idea.

ATUT51. Hands-on experience with Koha OSLIS is fun.

ATUT52. I like working with Koha OSLIS.

ATUT53. I need more practice on Koha OSLIS.

ATUT54. I need more exposure in using Koha OSLIS.

ATUT55. I find Koha OSLIS ease the library operations.

ATUT56. I find Koha OSLIS ease the library services.

Acceptance of Koha Open Source Library Information System (ATUKOSLIS)

ATUKOSLIS57. I am willing to use Koha OSLIS.

ATUKOSLIS58. I will support the use of Koha OSLIS.

ATUKOSLIS59. I will recommend Koha OSLIS to other libraries.

Sundaravej (2010)

ATUKOSLIS60. I will suggest my library to continue to use Koha OSLIS.

ATUKOSLIS61. I accept the use of Koha OSLIS in my library. 